\title{
STRATEGI PEMERINTAH KOTA PADANG DALAM PENGEMBANGAN PARIWISATA BERBASIS MITIGASI BENCANA
}

\author{
Erien Sri Wahyuni' ${ }^{\text {, Roni Ekha Putera }}{ }^{2}$ Yoserizal $^{3}$ \\ 1, 2, 3 Jurusan Administrasi Publik, Universitas Andalas \\ e-mail: roniekhaputera@soc.unand.ac.id
}

\begin{abstract}
This research in the background with Padang City is one of the cities that has existing tourism potential, where Padang City itself has vulnerability and vulnerability to disasters on existing tourist objects. This is a concern or concern for the city government of Padang if you want to develop tourism. On the one hand, Padang City has strong tourism potential, and on the other hand, Padang also has a high vulnerability to disasters. Thus, of course, the Padang City Government needs to create or manage tourism development strategies in disaster-prone areas. This study uses the theory of types of a plan initiated by Kotten. In this theory, there are four types of policies, namely: Organizational Strategy, Program Strategy, Resource Support Strategy, Institutional Strategy. The method used in this study is qualitative with a descriptive approach, data collection techniques used are interviews and documentation, while the method for selecting information is using a purposive sampling technique. To test the validity of the data obtained in the field, researchers used source triangulation. Based on the findings in the area, the Padang City Government has a strategy to develop tourism based on disaster mitigation, which through the Department of Tourism and Culture and the Padang City Regional Disaster Management Agency, has programs related to the development of disaster-based tourism mitigation.
\end{abstract}

Keywords: tourism development, disaster mitigation, padang

Received: 05 Mei 2020

Accepted: 20 Juni 2020

Published: 24 Juni 2020

\section{PENDAHULUAN}

Pariwisata merupakan salah satu sektor dan kegiatan yang mengalami pertumbuhan pesat. Walaupun terdapat berbagai faktor eksternal yang kurang menguntungkan perkembangan pariwisata, sampai saat ini masih dianggap sebagai sektor yang mempunyai pertumbuhan yang pesat dan memberikan kontribusi ekonomi bagi banyak negara maupun wilayah. Kegiatan wisata dinilai semakin penting peranannya dalam mewujudkan keberlanjutan dan kedinamisan kehidupan sosial dan perekonomian sehari-hari, banyak penduduk yang terlibat dalam kegiatan pariwisata baik sebagai wisatawan maupun sebagai pekerja (Rosyidie, 2004). Menurut Undang-Undang (UU) Pariwisata Nomor 10 tahun 2009, pariwisata adalah berbagai macam kegiatan wisata dan didukung berbagai fasilitas serta layanan yang disediakan oleh masyarakat, pengusaha, pemerintah, dan pemerintah daerah.

Pariwisata adalah keseluruhan kegiatan yang berhubungan dengan masuk, tinggal, dan pergerakan penduduk asing di dalam atau di luar suatu negara, kota, 
atau wilayah tertentu. Indonesia adalah negara yang memiliki sumber daya alam yang sangat melimpah, kekayaan seni budaya, adat istiadat, peninggalan sejarah, sehingga hal tersebut dapat menjadi potensi yang dapat dikembangkan dalam sektor pariwisata. Potensi wisata Indonesia yang memiliki kurang lebih 17.508 pulau dengan garis pantai sepanjang $81.000 \mathrm{~km}$ dan luas sekitar 3,1 juta $\mathrm{km}^{2}$ menyimpan sumber daya potensial (Samsudin, dkk, 2018).

Dengan kondisi alam yang begitu luar biasa indahnya tersebut didukung juga oleh berbagai potensi pariwisata yang dimiliki dan keberagamaan pariwisata yang ada seperti wisata alam, wisata buatan, wisata sejarah, dan wisata minat khusus. Dalam melakukan kunjungan, wisatawan mancanegara memerlukan berbagai macam sarana dan prasarana yang mendukung. Hal ini dapat dilihat dari jumlah wisatawan, baik wisatawan nusantara maupun wisatawan mancanegara, yang secara bertahap dan berkelanjutan mengalami peningkatan dari waktu ke waktu. Beberapa kawasan mengalami pertumbuhan pesat baik jumlah pengunjungnya maupun keragaman daya tarik yang ditawarkan. Berbagai jenis bentang alam dan fenomena sosial budaya dari berbagai negara atau daerah dimanfaatkan sebagai daya tarik wisata untuk dinikmati penduduk lokal maupun penduduk dari wilayah atau negara lain (Pahleviannur, dkk, 2019).

Dengan kondisi Indonesia yang memiliki wilayah yang luas dan terletak di garis khatulistiwa pada posisi silang antara dua benua dan dua samudera, berada dalam wilayah yang memiliki kondisi geografis, geologis, hidrologis, dan demografis yang rawan terhadap terjadinya bencana dengan frekuensi yang cukup tinggi. Indonesia berada di atas lempeng benua yang aktif dan berjejer deretan gunung api yang sangat aktif yang disebut dengan ring of fire. Kerentanan Indonesia terhadap bencana dipengaruhi oleh berbagai faktor antara lain faktor geografi, geologi, hidrometeorologi, demografi, lingkungan hidup, dan tata lahan (Sjafei, dkk, 2017).

Bencana alam merupakan suatu peristiwa yang ditimbulkan oleh bahaya alam dan perilaku manusia sehingga menyebabkan jatuhnya korban. Kecelakaan dan kematian pada manusia, kerugian harta benda, kerusakan sarana dan prasarana lingkungan hidup, kemerosotan kualitas sumber daya alam serta berubahnya ekosistem secara drastis. Bencana dapat terjadi di mana saja, kapan saja, dan pada siapa saja. Frekuensi terjadinya bencana sulit diprediksi, bisa terjadi hanya sekali dalam ratusan tahun, setahun sekali atau hanya pada musim tertentu. Sangat sulit untuk memprediksi di mana bencana alam akan terjadi, untuk berapa lama, dan berapa kuat/besar (Wilonoyudho, 2007).

Sumatera Barat saat ini menjadi salah satu daerah tujuan wisata di Indonesia, tidak hanya wisatawan nusantara, wisatawan mancanegara jumlahnya sudah cukup tinggi berkunjung ke Sumatera Barat. Para wisatawan ini dipengaruhi oleh faktor pendorong dan faktor penarik. Faktor pendorongnya adalah keinginan dari wisatawan sendiri untuk melakukan perjalanan wisata. Sedangkan faktor penariknya adalah faktor-faktor yang berasal dari objek wisata yang dikunjungi. Sumatera Barat memiliki bermacam-macam jenis wisata seperti wisata religi, wisata pertanian, wisata konvensi, wisata cagar alam, wisata bahari, wisata sejarah, dan wisata budaya (Sarbaitinil, dkk, 2018).

Salah satu daerah di Sumatera Barat yang memiliki potensi objek wisata yang yang menarik yaitu Kota Padang. Kota Padang memiliki banyak potensi wisata 
seperti wisata alam (air terjun, goa, hutan, pantai, pegunungan dan panorama alam), wisata budaya (benda dan bangunan cagar budaya, seni tradisional), wisata bahari (kunjungan pulau-pulau), wisata kuliner dan lain-lain. Semua wisata tersebut akan dikembangkan oleh pemerintah Kota Padang sehingga bisa menjadi destinasi wisata yang menarik dan layak untuk dikunjungi.

Kota Padang adalah salah satu daerah yang rentan terhadap bencana terutama gempa bumi dan tsunami. Pada tahun 2013, Padang termasuk dalam kategori tinggi dan rentan terhadap bencana serta menduduki peringkat ke-10 di tingkat nasional dan ke-1 di semua kabupaten/kota di Sumatera Barat. Posisi dan kondisi Padang yang terletak di cincin api Pasifik dan di zona subduksi antara lempeng Indo-Australia dan lempeng Eurasia menjadikan Padang salah satu daerah yang sering mengalami gempa. Adapun gempa besar yang terjadi pada 30 September 2009 menyebabkan banyak kerugian properti dan korban. Gempa bumi yang melanda Sumatera Barat yaitu di Kota Padang mengakibatkan ribuan korban jiwa dan ribuan rumah, fasilitas umum, serta infrastruktur hancur. Data menunjukkan bahwa di Padang ada 316 orang tewas, 4 orang hilang, 181 orang dengan luka serius, dan 425 orang dengan luka ringan (Putera, Nurasa, \& Sugandi, 2016).

Adapun dari permasalahan bencana alam yang terjadi di Kota Padang tetapi potensi Pariwisata yang ada di Kota Padang sendiri sangat tinggi. Potensi wisata yang paling banyak ada di Kota Padang adalah wisata budaya sebanyak 79 objek wisata. Setelah itu diikuti dengan perkembangan wisata belanja sebanyak 41 objek, dan wisata bahari sebanyak 32 objek. Perkembangan jumlah objek wisata di masing- masing kecamatan ini berjumlah tersebar merata. Objek wisata yang ada di Kota Padang yang paling diminati wisatawan adalah wisata bahari (Yanti, 2018). Oleh karena itu, Kota Padang dalam pengembangan pariwisata berbasis mitigasi bencana. Adapun objek wisata yang ada di kota Padang memiliki resiko terhadap bencana, terutama bencana alam seperti gempa bumi, tsunami dan lain sebagainya.

\section{METODE PENELITIAN}

Penelitian ini merupakan penelitian kualitatif dengan tipe deskriptif. Metode pengumpulan data yang dilakukan dalam penelitian ini adalah dengan melakukan Wawancara, observasi, dan dokumentasi. Komponen yang diamati adalah strategi organisasi, strategi program, strategi sumber daya, dan strategi lembaga. Cara penyajian data yang dilakukan dalam penelitian ini secara deskriptif, dengan tujuan untuk mendeskripsikan fenomena atau kejadian yang berlangsung di lapangan. Teknik pengumpulan data yaitu dengan wawancara, dokumentasi, dan observasi. Teknik analisis data dalam penelitian kualitatif akan berlangsung bersamaan dengan bagian-bagian lain dari pengembangan penelitian kualitatif, yaitu pengumpulan data dan penulisan temuan.

\section{HASIL PENELITIAN DAN PEMBAHASAN \\ Strategi Pemerintah Kota Padang dalam Pengembangan Pariwisata Berbasis Mitigasi Bencana}

Pengembangan merupakan suata cara atau usaha untuk mengembangkan sesuatu ke arah yang baik, sedangkan pariwisata sendiri merupakan suatu perjalanan yang dilalukan oleh seorang traveller atau tourist secara berulang-ulang 
(Salusu, 1996). Pada saat sekarang ini perkembangan pariwisata merupakan sebuah fenomena besar, dengan banyaknya tempat-tempat pariwisata yang sudah berkembang di Sumatera Barat tentu setiap kota/kabupaten memiliki strategi dalam mengembangkan pariwisatanya masing-masing. Strategi ialah suatu seni menggunakan kecakapan dan sumber daya suatu organisasi untuk mencapai sasarannya melalui hubungannya yang efektif dengan lingkungan dalam kondisi yang paling menguntungkan (Salusu, 1996).

\section{Strategi Organisasi}

\section{a. Tujuan Organisasi}

Tujuan yang dimaksud disini adalah visi organisasi, visi pada dasarnya adalah kondisi masa depan yang diharapkan dapat dicapai dalam kurun waktu tertentu. Visi berkaitan dengan pandangan ke depan menyangkut kemana organisasi harus dibawa dan diarahkan agar dapat bekarya secara konsisten dan tetap eksis, antisipatif, inovatif serta produktif (Salusu, 1996). Pemerintah Kota Padang dalam pencapaian tujuan organisasi secara umum ingin mewujudkan pendidikan masyarakat agar lebih baik lagi dan melalui pendidikan akan dapat pula ditingkatkan kemampuan masyarakat untuk dapat memahami dan memanfaatkan Ilmu Pengetahuan dan Teknologi (IPTEK) sehingga dapat mewujudkan pembangunan Kota Padang yang lebih baik. Sementara itu di bidang perdagangan ada keinginan pemerintah kota mewujudkan jiwa wirausaha masyarakat kota Padang yang relatif lebih baik merupakan faktor pendorong utama untuk mendorong kegiatan perdagangan tersebut. Pemerintah Kota (Pemkot) Padang juga ingin mengembangkan sektor pariwisata yaitu pariwisata bahari karena pariwisata juga dapat meningkatkan pertumbungan ekonomi bagi masyarakat Kota Padang dan serta pengembangan objek wisata berbasis mitigasi bencana, karena Kota Padang merupakan salah satu destinasi wisata di Indonesia dan juga merupakan daerah rawan bencana. Dalam mencapai tujuan suatu organisasi, dimana organisasi tersebut membuat suatu program atau kegiatan agar mencapai suatu tujuan dan juga visi dari organisasi tersebut. Mengenai visi ini, berdasarkan hasil wawancara dengan Walikota Padang mengatakan bahwa:

"...dalam mencapai visi yang telah kita bentuk ini maka kita melakukan berbagai strategi agar dapat mencapainya, dimana pendidikan di Kota Padang saat ini sudah mulai bekembang dengan baik dan di sekolah-sekolah juga sudah memanfaatkan ilmu pengetahuan dan teknologi (IPTEK) seperti contohnya di siswa-siswa telah melakukan prensentasi di kelas dan ujian tulis berbasis komputer. Sedangkan di bidang perdagangan dimana pemerintah kota padang sudah memberikan fasilitasfasilitas bagi masyarakat atau pedagang-pedagang untuk berjualan ditempat yang lebih layak dan tertata rapi. Lalu di bidang pariwisata sendiri kita mengembangkan berbagai potensi wisata yang dimiliki Kota Padang terutama wisata bahari dan juga pengembangan objek wisata berbasis mitigasi bencana, karena Kota Padang merupakan salah satu destinasi wisata di Indonesia dan juga merupakan daerah rawan bencana seperti pembangunan selter dan adanya pemasangangan ramburambu jalur evakuasi" (Hasil wawancara dengan bapak Walikota Padang Pak Mahyeldi Ansharullah, tanggal 17 Maret 2020, jam 19.30).

Dari hasil wawancara peneliti tersebut dapat diketahui bahwa Walikota Padang berupaya dengan baik agar dapat mewujudkan dan mencapai visi yang telah dibentuk agar dapat memajukan dan menyejahterakan masyarakat Kota Padang. Pemkot Padang melakukan strategi-strategi atau langkah-langkah agar 
dapat mencapainya dengan membuat kegiatan-kegiatan yang berhubungan degan visi tersebut.

\section{b. Misi Organisasi}

Misi merupakan upaya yang harus dilaksanakan oleh seluruh perangkat organisasi untuk mewujudkan visi yang telah diterapkan. Visi merupakan sesuatu yang ingin dicapai dalam waktu yang akan datang atau bisa diartikan dalam jangka waktu tertentu dan setelah itu visi tersebut dijabarkan ke dalam misi. Misi merupakan langkah-langkah atau strategi yang dilakukan oleh Pemerintah Kota dalam mewujudkan sebuah visi (Salusu, 1996).

Dari beberapa misi yang dimiliki oleh Walikota Padang ada salah satu poin yang berhubungan dengan pariwisata yaitu meningkatkan pengelolaan pariwisata yang nyaman dan berkesan. Dimana untuk mewujudkan pariwisata yang nyaman dan berkesan tersebut pemerintah memiliki cara agar membuat wisatawan nyaman berada di Kota Padang, adapun potensi bencana yang dimiliki Kota Padang sendiri itu dapat mengakibatkan ketakutan bagi wisatawan dan merasa tidak nyaman saat berwisata di Kota Padang. Pemerintah Kota harus memiliki strategi yang dilakukan untuk mengatasi hal tersebut sebagaimana yang disampaikan oleh Walikota Padang:

"..Maka dari itu kita pemerintah Kota Padang menyiapkan bangunan-bangunan kemudian juga kita menyediakan akses, dimana kita tau bahwa objek wisata kita yang utama yaitu di daerah pantai maka dari itu kita menyiapkan jalur evakuasi bagi wisatawan. Bangun-bangunan yang kita siapkan itu yang tahan gempa 9 SR seperti bangunan sekolah dan pasar" (Hasil wawancara dengan bapak Walikota Padang Pak Mahyeldi Ansharullah, tanggal 17 Maret 2020, jam 19.30).

Berdasarkan visi dan misi dari Walikota Padang yang mana meningkatkan kualitas pengelolaan pariwisata yang nyaman dan berkesan serta menciptakan masyarakat sadar, peduli, dan tangguh bencana. Maka dari itu dalam pengembangan pariwisata di Kota Padang harus memikirkan kenyamanan dan berkesan bagi wisatawan yang berkunjung ke objek wisata yang ada di Kota Padang, dimana rentannya resiko bencana yang terjadi itu dapat menyebabkan kurang nyamannya wisatawan mancanegara dan domestik. Wisatawan juga harus lebih sadar, peduli, dan tangguh terhadap bencana yang akan terjadi. Pemerintah Kota Padang dalam mencapai misinya tersebut memiliki strategi-strategi yang dilakukan seperti yang dikatakan oleh Walikota Padang, yang mana agar dapat mewujudkan pariwisata Kota Padang ini menjadi lebih nyaman dan berkesan. Dari upaya yang disampaikan oleh Walikota Padang tersebut dapat juga membuat rasa aman bagi wisatawan-wisatawan mancanegara maupun wisatawan domestik.

\section{Strategi Program}

\section{a. Program dan Kegiatan Organisasi}

Program adalah pernyataan aktivitas-aktivitas atau langkah-langkah yang diperlukan untuk menyelesaikan perencanaan sekali pakai. Program dan kegiatan yang dilaksanakan dari sebuah organisasi dilakukan untuk mencapai tujuan dan sasaran bagi organisasi tersebut. Pelaksanaan program tersebut diharapkan dapat mencapai visi dan misi dari suatu organisasi (Salusu, 1996). 
Program yang dilakukan oleh Dinas Pariwisata Kota Padang yang berhubungan dengan Pengembangan Pariwisata Berbasis Mitigasi Bencana yaitu Badan Penyelamat Wisata Tirta (BALAWISTA), dimana program ini bertujuan agar meningkatkan kapasitas para relawan keamanan dan mengurangi angka kecelakaan dan korban bencana. Program BALAWISTA memberikan pengetahuan dan pemahaman tentang pengembangan sumber daya manusia dalam rangka meningkatkan pengetahuan dan keterampilan dalam bentuk pelatihan-pelatihan tanggap darurat. Dan juga tukar menukar informasi dalam rangka meningkatkan kegiatan pelayanan kepada masyarakat. Kegiatan BALAWISTA ini dilakukan selama 3 hari (19-21 februari 2020) di Hotel Grand Inna yang diikuti oleh 40 peserta. Dimana Dinas Pariwisata dan Kebudayaan Kota Padang mengharapkan output yaitu terlatihnya 40 orang yang paham tentang keterampilan dalam bentuk tanggap darurat dari penyelamatan.

Dalam pengembangan pariwisata berbasis mitigasi bencana di Kota Padang tidak hanya melalui program BALAWISTA saja, tetapi Badan Penanggulangan Bencana Daerah (BPBD) Kota Padang juga memiliki kegiatan peyediaan sarana seperti baliho mengenai bencana, plang jalur evakuasi, dan shelter. Badan Penanggulangan Bencana Daerah (BPBD) Kota Padang dapat membantu masyarakat maupun wisatawan melalui baliho dan plang petunjuk jalur evakuasi yang mana wisatawan dapat membaca dan mengetahui apa yang harus dilakukan ketika terjadi bencana.

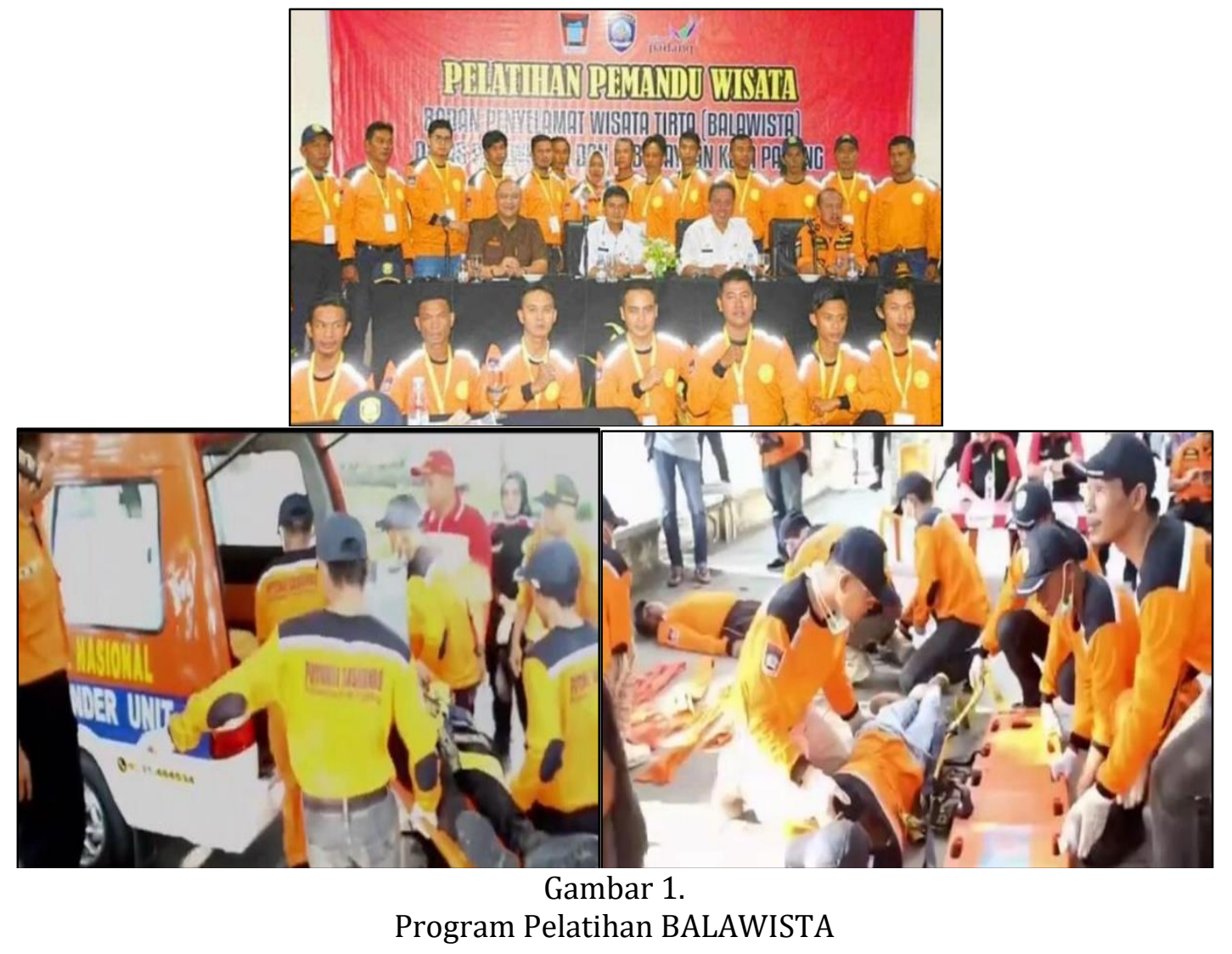

Jurnal Pendidikan IImu Sosial, Vol 30, No.1, Juni 2020,

p-ISSN: 1412-3835; e-ISSN: 2541-4569 


\section{b. Dampak Program terhadap Sasaran Organisasi}

Program yang dilakukan oleh Dinas Pariwisata Kota Padang yang berhubungan dengan Pengembangan Pariwisata Berbasis Mitigasi Bencana yaitu Badan Penyelamat Wisata Tirta (BALAWISTA), dimana program ini bertujuan agar meningkatkan kapasitas para relawan keamanan dan mengurangi angka kecelakaan dan korban bencana. Program BALAWISTA memberikan pengetahuan dan pemahaman tentang pengembangan sumber daya manusia dalam rangka meningkatkan pengetahuan dan keterampilan dalam bentuk pelatihan-pelatihan tanggap darurat. Selain itu juga sarana tukar menukar informasi dalam rangka meningkatkan kegiatan pelayanan kepada masyarakat.

Program BALAWISTA ini sangat penting karena adanya BALAWISTA ini membuat masyarakat maupun wisatawan yang datang ke Kota Padang pun tidak takut apabila terjadi bencana karena mereka merasa aman dan juga anggota BALAWISTA ini sudah dilatih dengan sebaik-baiknya oleh pihak Dinas Pariwisata dan Kebudayaan Kota Padang, BPBD Kota Padang, dan Badan SAR Nasional (BASARNAS) Kota Padang. Maka dari itu Kota Padang dapat meningkatkan pengembangan potensi wisata yang dimiliki dan dapat meyakinkan wistawan untuk datang ke Kota Padang.

Dampak program dan kegiatan yang dilakukan oleh Dinas Pariwisata dan Kebudayaan Kota Padang sangat berdampak baik terhadap organisasinya karena dapat mencapai visi misi yang telah dibentuk dan dilakasanakan melalui kegiatan atau program yang telah dilaksanakan. Serta dapat mencapai peningkatan terhadap wisatawan domestik maupun mancanegara karena mereka merasa nyaman dan aman apabila berkunjug ke Kota Padang, dimana adanya tim penyelamat yang selalu standby di daerah wisata.

Program yang dibuat oleh Dinas Pariwisata dan Kebudayaan Kota Padang ini sangat berdampak baik bagi organisasinya juga berdampak baik bagi masyarakat. Adapun melalui program ini wisatawan merasa lebih aman dan nyaman berkunjung ke wisata yang ada di Kota Padang. Tidak hanya berdampak terhadap bagi wisatawan dan organisasi itu saja tapi juga berdampak kepada Pemerintah Kota Padang yang mana dapat mencapai visi misi Walikota Padang.

Adapun kegiatan yang dilakukan oleh Badan Penanggulangan Bencana Daerah (BPBD) yang berkaitan dengan pengembangan pariwisata berbasis mitigasi bencana yang mana seperti baliho/plang bencana, plang jalur evakuasi dan shelter. Dimana kegiatan tersebut memberikan dampak yang baik bagi organisasinya dan juga membantuk pemerintah kota dalam pengembangan pariwisata yang berbasis mitigasi bencana. Adanya kegiatan tersebut juga berdampak baik bagi wisatawan dan masyarakat yang mana dari kegiatan itu dapat membantu masyarakat dan wisatawan ketika terjadi bencana.

\section{Strategi Sumber Daya}

\section{a. Sumber Daya Manusia}

Sumber daya manusia adalah adalah potensi manusia yang merupakan aset dan berfungsi sebabagi modal non material, non finansial di dalam organisasi yang dapat diwujudkan menjadi potensi nyata secara fisik dan non fisik dalam mewujudkan strategi organisasi. Sumber Daya Manusia (SDM) adalah aset yang paling penting dalam sebuah perusahaan atau organisasi. Karyawan dapat menjadi 
potensi bila dikelola dengan baik dan benar, tetapi akan menjadi beban apabila salah kelola (Salusu, 1996).

Sumber daya manusia merupakan kunci yang sangat menentukan perkembangan suatu organisasi, pada hakikatnya sumber daya manusia merupakan sumber daya yang memanfaatkan manusia sebagai tenaga yang dipekerjakan di sebuah organisasi untuk mencapai sebuah tujuan dari organisasi tersebut. Berdasarkan jumlah pegawai dengan tingkat pendidikan yang dimiliki oleh Dinas Pariwisata dan Kebudayaan serta BPBD Kota Padang sangat berpengaruh terhadap kinerja dalam menjalani suatu program yang telah dibentuk oleh organisasi tersebut.

Bahwa tingkat pendidikan pegawai di dalam suatu organisasi sangat mempengaruhi tingkat kinerja dalam menjalankan suatu program dan kegiatan, dapat dilihat bahwa di Dinas Pariwisata dan Kebudayaan serta BPBD Kota Padang mempunyai jumlah pegawai yang berbeda-beda dalam tingkat pendidikannya. Hal ini dibenarkan oleh Kepala Dinas Pariwisata dan Kebudayaan Kota Padang, mengatakan bahwa:

“...mengenai sumber daya manusia di Dinas Pariwisata dan Kebudayaan ini, kami memiliki puluhan lebih pegawai dimana setiap tahunnya berbeda-beda dan tingkatan pendidikan yang paling rendah yaitu SD, tetapi itu hanya pada tahun 2015-2016 yang man pada tahun selanjutnya kami tidak menerima lagi tamatan SD, sedangkan yang paling tinggi yaitu S3 yang mana pendidikan yang paling didominasi atau banyak yaitu S2 dimana hal ini pasti berpengaruh terhadap kinerja pegawai" (Hasil Wawancara dengan Bapak Arfian Kepala Dinas Pariwisata dan Kebudayaan Kota Padang, tanggal 02 Maret 2020, pukul 16.00).

Tingkat pendidikan pegawai di dalam suatu organisasi sangat mempengaruhi tingkat kinerja dalam menjalankan suatu program dan kegiatan, dapat dilihat bahwa di Dinas Pariwisata dan Kebudayaan Kota Padang mempunyai jumlah pegawai yang berbeda-beda dalam tingkat pendidikannya. Maka dari itu untuk meningkatkan kinerja pegawai organisasi tersebut dapat memberikan pelatihanpelatihan kepada pegawai agar bisa menambah wawasan dan ilmu pengetahuan sumber daya manusia yang dimilikinya.

\section{b. Sarana dan Prasarana}

Sarana adalah segala sesuatu jenis peralatan, perlengkapan kerja dan fasilitas yang berfungsi sebagai alat utama dalam pelaksanaan pekerjaan dan juga dalam rangka kepentingan yang sedang berhubungan dengan organisasi kerja. Prasarana merupakan alat penunjang dari sarana. Sarana dan prasarana yang tersedia juga merupakan komponen yang penting dalam pengembangan pariwisata berbasis mitigasi bencana (Salusu, 1996).

Untuk fasilitas yang ada di dalam kawasan wisata tidak hanya oleh Pemerintah Kota Padang melainkan di dalam pengembangan pariwisata berbasis mitigasi bencana juga adanya sarana prasarana yang dibangun oleh pihak swasta dan juga masyarakat. Kemudian dalam pengembangan pariwisata berbasis mitigasi bencana juga melibatkan OPD terkait dalam strategi pendukung sumber daya. Sarana dan prasarana dalam pengembangan pariwisata berbasis mitigasi bencana seperti perlengkapan untuk anggota BALAWISTA, baliho kebencanaan di sekitar objek wisata, plang jalur evakuasi dan shelter. 


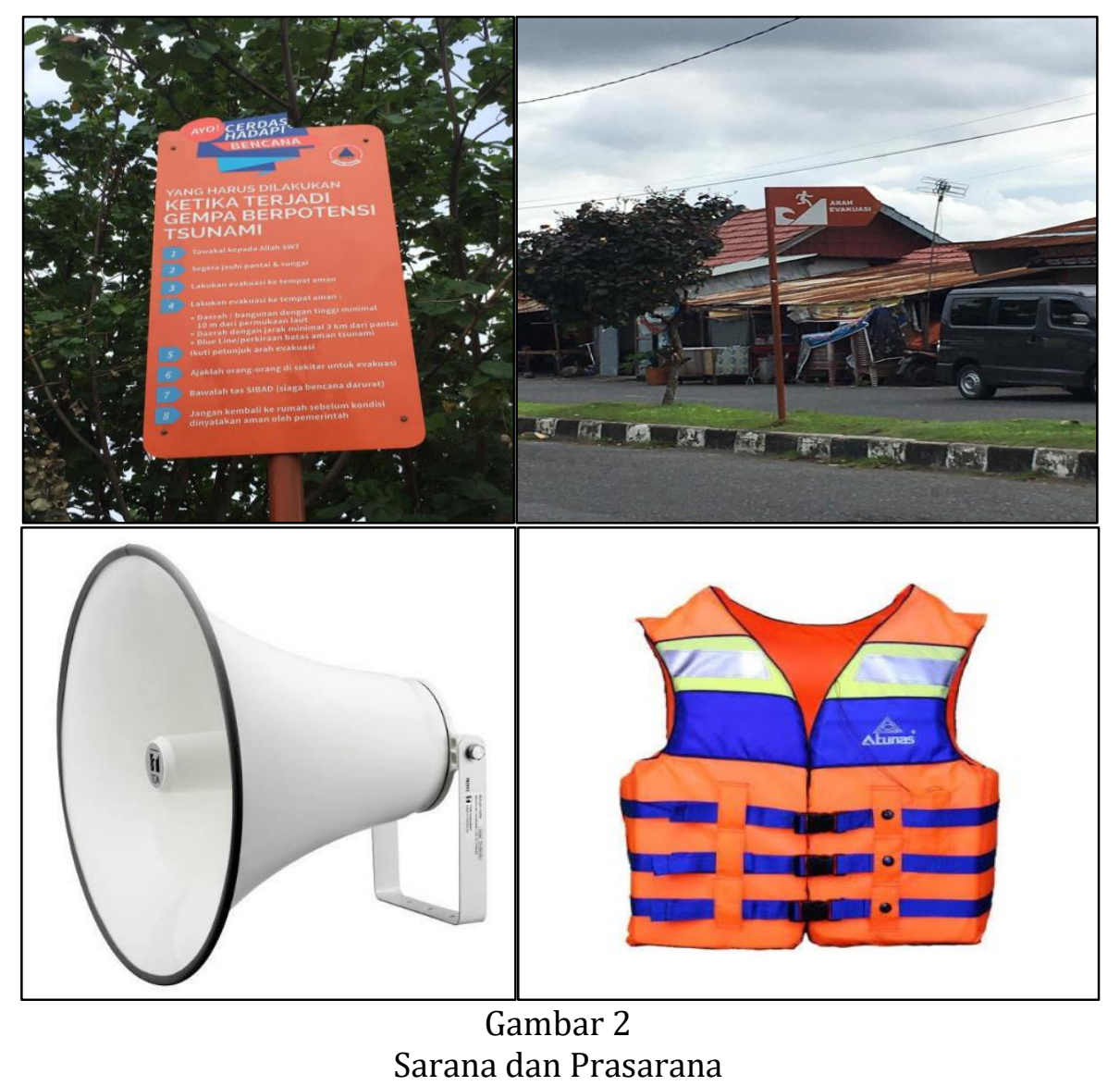

\section{c. Sumber Finansial}

Keuangan merupakan salah satu faktor yang sangat penting dalam setiap kegiatan organisasi. Suatu kegiatan tidak akan dapat berjalan dengan baik jika tidak didukung oleh ketersediaan finansial dalam suatu organisasi. Anggaran biasanya dinyatakan dalam bentuk angka yang menunjukkan sejumlah uang. Tanpa adanya anggaran yang mencukupi maka suatu instansi atau organisasi akan sulit untuk berkembang. Faktor keuangan sangat menentukan kelanjutan suatu organisasi tersebut, walaupun di suatu organisasi tersebut memiliki sumber daya manusia yang handal tanpa adanya anggaran akan mengalami kesulitan (Salusu, 1996).

Sumber daya finansial tidak menjadi penghambat oleh Dinas Pariwisata dan Kebudayaan Kota Padang dalam menjalankan program dan kegiatannya dalam pengembangan pariwisata, dapat dikatakan juga poin mengenai sumber daya finansial menurut Koteen (1991) (Salusu, 1996) ini terpenuhi dengan baik karena tidak adanya hambatan yang dialami oleh organisasi tersebut dalam bidang anggaran tersebut. Adapun BPBD Kota Padang dalam pelaksanaan program dan kegiatannya yang berkaitan dengan anggaran BPBD Kota Padang mengalami kendala dan terbatasnya anggaran. Dimana semua anggaran yang telah disediakan untuk memenuhi program dan kegiatan yang akan dijalankan itu sangat terbatas dan sangat sulit untuk menjalankan program dan kegiatan.

Berdasarkan hasil temuan peneliti di lapangan dan wawancara di atas dapat dianalisis bahwa tipe strategi dukungan sumber daya Koteen telah dilaksanakan namun dalam pelaksanaannya tidak berjalan dengan baik. Seperti sumber daya 
manusia di BPBD Kota Padang terbatasnya sumber daya manusianya membuat terkendala jalannya program dan kegiatan. Berbeda dengan sumber daya finansial, Dinas Pariwisata dan Kebudayaan Kota Padang memiliki anggaran yang cukup dalam melaksanakan pengembangan pariwisata di Kota Padang sehingga tidak memiliki kendala anggaran dalam pengembangan pariwisata. Sedangkan BPBD Kota Padang mengalami masalah karena terhalang keterbatasan anggaran yang dimiliki dan sulit untu menjalankan prorgam dan kegiatan yang telah dibentuk.

\section{Strategi Kelembagaan}

\section{a. Struktur dan Kewenangan}

Strategi kelembagaan ini menyangkut struktur serta kewenangan lembaga dan instansi yang bertugas melakukan strategi-strategi yang akan dilakukan oleh organisasi. Wewenang lembaga merupakan unsur penting yang menjalankan strategi bagaimana strategi yang dilakukan organisasi dalam menjalankan program dan kegiatan. Struktur organisasi dapat didefinisikan sebagai suatu sistem atau jaringan kerja terhadap pembagian kerja, sistem pelaporan, dan komunikasi yang menghubungkan secara bersama pekerjaan kepada kelompok atau devisi pekerjaan sehingga organisasi terlaksana dengan baik. Yang dimaksud disini adalah cara organisasi terstruktur dan siapa melapor kepada siapa, juga struktur organisasi yang mengatur sistem kerja, komunikasi, wewenang dan tanggung jawab serta pelimpahan tugas kepada unit kerja atau orang-orang tertentu untuk mencapai sasaran organisasi (Salusu, 1996).

Kewenangan merupakan otoritas atau legitimasi bagi para pelaksana dalam melaksanakan kebijakan yang ditetapkan secara politik. Kewenangan berkaitan dengan struktur birokrasi yang melekat pada posisi atau strata kelembagaan atau individu sebagai pelaksana kebijakan. Karakteristik utama dari birokrasi umumnya tertuang dalam prosedur kerja atau Standard Operating Procedures (SOP) dan fragmentasi organisasi. Pada dasarnya struktur ini bagaimana sebuah departemen atau koordinator mengkoordinasikan suatu kegiatan kemudian apakah anggotanya bisa menyesuaikan diri dalam kegiatan tersebut, hal ini tergantung mengenai jalur komunikasi yang digunakan, sesuai dengan keharusan terhadap apa yang dilakukan. Begitu juga halnya dengan struktur organisasi yang dimiliki oleh Dinas Pariwisata dan Kebudayaan Kota Padang dan BPBD Kota Padang, dimana dalam menjalankan segala kegiatannya mereka memiliki struktur dan bidang yang bertanggung jawab di masing-masing bidang yang mana menjadi tanggung jawab mereka.

\section{b. Kebijakan dan Peraturan Yang Dimiliki}

Terkait dengan tugas pokok dan fungsinya. Peraturan dapat berupa peraturan legal ataupun hanya imbauan (informasi) yang bersifat tidak terlalu mengikat. Salah satu dari aspek yang penting dari setiap organisasi ataupun lembaga adalah adanya Prosedur Operasi yang Standar (SOP). SOP yaitu dokumen yang berisi serangkaian instruksi tertulis yang dilakukan mengenai berbagai proses penyelenggaraan administrasi perkantoran yang berisi cara melakukan pekerjaan, waktu pelaksanaan, tempat penyelenggaraan dan aktor yang berperan dalam kegiatan (Salusu, 1996). 
Di dalam SOP perumusan dan penyusunan rencana teknis pengembangan kepariwisataan pelaksanaannya dimulai dengan Kepala Bidang (Kabid), dimana Kepala Bidang ini menugaskan Kepala Seksi (Kasi) Destinasi untuk menyusun Rencana Teknis dalam Pengembangan kepariwisataan kemudian turun ke Kepala Seksi, dimana nanti Kasi Destinasi menyiapkan konsep tentang rencana teknis kemudian turun ke JFU (Jabatan Fungsional Umum), dimana disini tugas JFU mengetik konsep yang sudah disiapkan oleh Kasi Destinasi kemudian dikembalikan lagi ke Kepala Seksi, dimana disini konsep yang sudah diketik oleh JFU diperiksa terlebih dahulu sebelum disampaikan kepada Kepala Bidang dan dikembalikan lagi ke Kepala Bidang, dan disini Kepala bidang memeriksa jika ada kesalahan maka akan dikembalikan dan disuruh revisi dan dari Kepala Bidang itu ke Sekretaris, disini seketaris memeriksa dengan teliti dokumen tersebut dan dari Sekretaris barulah ke Kepala Dinas, disini setelah diteliti oleh Sekretaris maka Kepala Dinas menyetujui dan menandatangani dan dari Kepala Dinas turun lagi ke JFU, dimana JFU disini tugasnya mengarsipkan dokumen yang sudah disetujui dan ditanda tangani oleh Kepala Dinas. Prosedur kerja yang dilakukan dilihat dari tupoksi masing-masing. Sebagaimana yang disampaikan oleh Staf Bidang Kesekretariatan Dinas Pariwisata dan Kebudayaan Kota Padang:

“...kegiatan yang kami lakukan mengacu kepada SOP ini dan Tupoksi yang sudah ada sebelumnya dan kami harus mematuhi SOP tersebut serta tidak boleh melenceng dari hal tersebut" (Hasil wawancara dengan Bapak Okdeli Staf Bidang Kesekretariatan, tanggal 02 Maret 2020 pukul 13.00).

Adapun peneliti juga melakukan wawancara dengan Kabid Pencegahan dan Kesiapsiagaan Badan Penanggulangan Bencana Daerah mengatakan :

“...ya dalam menjalankan pekerjaan kami pasti sesuai dengan SOP yang telah ditetapkan dan kami tidak bisa melanggar hal tersebut serta kami dalam menjalan program dan kegiatan juga sesuai dengan SOP" (Hasil wawancara dengan Bapak Henry Kabid Pencegahan dan Kesiapsiagaan, pada tanggal 28 Februari pukul 11.30).

Berdasarkan hasil wawancara di atas dapat dikatakan bahwa Dinas Pariwisata dan Kebudayaan Kota Padang serta BPBD Kota Padang merupakan instansi yang bertanggung jawab dalam pengembangan pariwisata berbasis mitigasi bencana. Setiap program dan kegiatan yang dilakukan oleh instansi tersebut telah mengacu atau sesuai dengan tupoksi dan SOP yang telah ditetapkan sebelumnya, juga Dinas Pariwisata dan Kebudayaan Kota Padang serta BPBD melakukan kegiatan-kegiatan yang dapat mencapai tujuan organisasi.

\section{KESIMPULAN}

Berdasarkan penjelasan temuan dan analisis di atas, dapat disimpulkan bahwa Pemerintah Kota yaitu Dinas Pariwisata dan Kebudayaan Kota Padang dan Badan Penanggulangan Bencana Daerah (BPBD) Kota Padang telah melakukan strategi dalam pengembangan pariwisata berbasis mitigasi bencana di Kota Padang. Dimana dalam Dinas Pariwisata dan Kebudayaan Kota Padang dan BPBD Kota Padang menjalankan beberapa strategi. Dimana strategi organisasi, strategi kelembagaan sudah terlaksana dengan baik, sedangkan strategi program dan strategi dukungan sumber daya belum berjalan dengan baik. Dinas Pariwisata dan Kebudayaan Kota Padang dan BPBD Kota Padang mempunyai visi, misi dan tujuan dalam menjalankan organisasi, mempunyai program-program dan kegiatan yang 
harus dilakukan, mempunyai sumber daya manusia, finansial yang cukup, dan mempunyai standar operasional prosedur dalam melaksanakan seluruh kegiatan organisasi. Namun dalam pelaksanaan tipe strategi Koteen tersebut tidak seluruhnya berjalan dengan baik, salah satunya strategi program yang dilaksanakan untuk pengembangan pariwisata berbasis mitigasi bencana. Jadi, dalam pelaksanaan strategi berdasarkan tipe strategi Koteen yang dilakukan oleh Dinas Pariwisata dan Kebudayaan Kota Padang dan Badan Penanggulangan Bencana Daerah Kota Padang tidak seluruhnya berjalan dengan baik.

\section{DAFTAR PUSTAKA}

Pahleviannur, M.R, dkk. 2019. Strategi Perencanaan Pengembangan Pariwisata Untuk Mewujudkan Destinasi Tangguh Bencana di Wilayah Kepesisiran Drini Gunungkidul. Jurnal Pendidikan Ilmu Sosial. 29 (2).

Putera, R. E, H. Nurasa, Y.S. Sugandi. 2016. Synergizing Stakeholders in Reducing Risk of Earthquake and Tsunami-Disaster in the Most Vulnerable Area. International Journal of Administrative Science \& Organization. 23 (3).

Rosyidie, A. 2004. Aspek Kebencanaan Pada Kawasan Wisata. Wisata Jurnal Perencanaan Wilayah dan Kota.

Salusu, J. 1996. Pengambikan Keputusan Strategik untuk Organisasi Publik dan Organisasi Non Profit. Jakarta: Grasindo.

Samsudin, A., dkk. 2018. Strategi Dinas Pariwisata Dalam Pengembangan Objek Wisata Pulau Bawah Di Kabupaten Kepulauan Anambas.

Sarbaitinil, dkk. 2018. Educational Opportunity Wisatawan Dalam Melakukan Perjalanan Wisata dan Pengaruhnya Terhadap Tingkat Pengetahuan dan Kepuasan Wisatawan di Sumatera Barat. Jurnal Pariwisata Pesona. 03 (1).

Sjafei, S. dkk. 2017. Mitigasi Bencana Tsunami Melalui Pariwisata. Jurnal Ilmu Kebencanaan, 4 (2).

Undang-Undang (UU) Nomor 10 tahun 2009 tentang Kepariwisataan.

Wilonoyudho, S. 2007. Perencanaan Kota Berbasis Manajemen Bencana. Jurnal Teknik Sipil dan Perencanaan, 9 (2)

Yanti, N. 2018. Analisis Pengembangan Sektor Pariwisata Di Kota Padang. Journal of Economic and Management Scienties, 1 (1), 30 - 39. 